\title{
Arteriovenous malformation of the inferior mesenteric artery in a patient with ischaemic colitis
}

\author{
Veysel Akgun, ${ }^{1}$ Sebahattin Sari, ${ }^{1}$ Samet Verim, ${ }^{2}$ Ugur Bozlar $^{1}$
}

${ }^{1}$ Department of Radiology, Gulhane Military Medical Academy, Ankara, Turkey ${ }^{2}$ Department of Radiology, Mevki Military Hospital, Ankara, Turkey

\section{Correspondence to}

Veysel Akgun,

akgunveysel@yahoo.com

\section{DESCRIPTION}

A 48-year-old man with ulcerative colitis was admitted to our hospital due to abdominal pain. He had no history of abdominal trauma or surgery. His abdominal x-ray showed dilated colonic segment suggestive of toxic megacolon. He was haemodynamically stable. Stool studies were negative for infection. Ultrasonography was normal other than minimal peri-intestinal free fluid. Colonoscopy demonstrated erythema and friable mucosa in the colonic segments. Consecutive colonic biopsies revealed mucosal oedema and prominent capillaries, consistent with a congestive process compatible with bowel ischaemia. Thereafter, the patient was referred to our department for further imaging of the mesenteric vessels. Multidetector CT angiography showed severe stenosis in the origin of inferior mesenteric artery (IMA) and an additional arteriovenous malformation (AVM) involving the proximal IMA (figure 1). Increased calibration of the IMA, early filling of inferior mesenteric and portal veins can be readily seen despite the arterial timing of the study. Additionally, there is diffuse thickening of the colonic segments that are mainly perfused by IMA (figure 1).

Accordingly, the patient was diagnosed to have an AVM arising from the IMA and ischaemic bowel disease; he underwent total colectomy with (a)

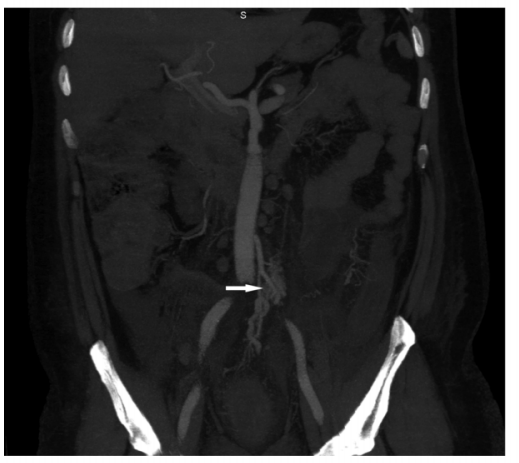

(c)

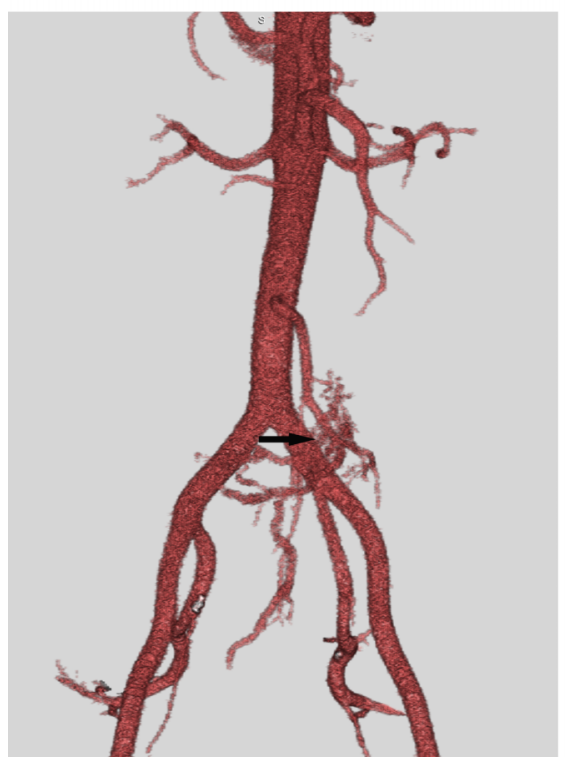

(b)

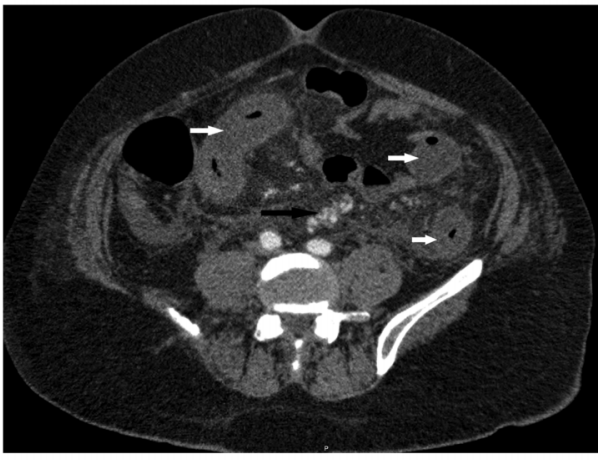

(d)

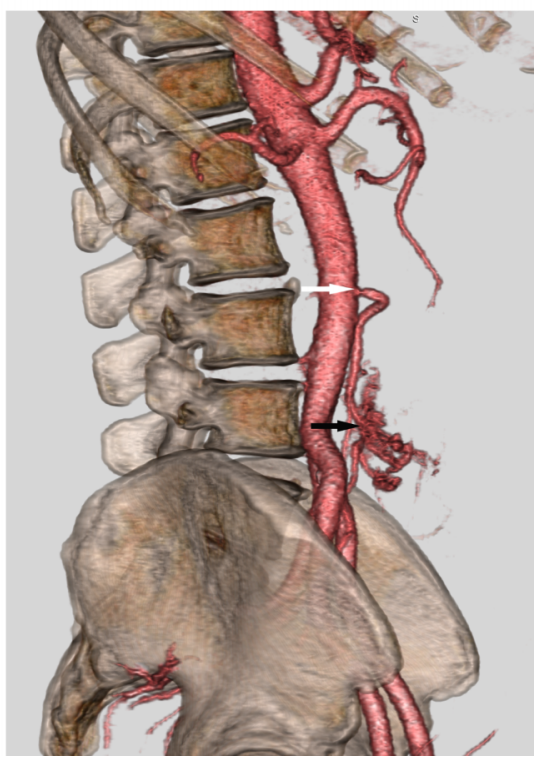

To cite: Akgun V, Sari $S_{\text {, }}$ Verim $\mathrm{S}$, et al. BMJ Case Rep Published online:

[please include Day Month Year] doi:10.1136/bcr-2013009565
Figure 1 (A) Coronal maximum intensity projection CT angiography image shows arteriovenous malformation originating from inferior mesenteric artery (arrow). (B) Axial CT image shows multiple abnormal vascular structures around to inferior mesenteric artery (black arrow) and marked thickening of colonic wall segments (white arrows). Frontal (C) and lateral (D) views of coloured three-dimensional volume rendered CT angiography images show arteriovenous malformation nidus (black arrow) of inferior mesenteric artery (IMA) (C and D) and severe stenosis of orifice of the IMA (white arrow). 
terminal ileostomy. Histopathological examination confirmed the diagnosis and his recovery was uneventful.

AVMs can be seen in any part of the body, and mesenteric AVMs are quite rare. ${ }^{1}$ Their clinical findings are generally those of abdominal pain, palpable mass and portal hypertension or occasionally intestinal ischaemia. ${ }^{2}$ In cases with intestinal ischaemia, the possible diagnosis of an AVM should also be kept in mind aside from other common causes such as emboli or thrombosis. ${ }^{3}$

\section{Learning points}

- Arteriovenous malformation (AVM) is a rare cause of ischaemic abdominal pain.

- In cases with intestinal ischaemia, the possible diagnosis of an AVM should also be kept in mind.

- AVM can be readily diagnosed by multidetector CT-angiography.
Competing interests None.

Patient consent Obtained.

Provenance and peer review Not commissioned; externally peer reviewed.

\section{REFERENCES}

1 Gorospe EC, Leggett CL, Sun G. Inferior mesenteric arteriovenous malformation: an unusual cause of ischemic colitis. Ann Gastroenterol 2012;25:165.

2 Sato 0 , Okamoto $H$, Matsumoto $H$. Emergency CT scan for the diagnosis of superior mesenteric embolism: report of 2 cases. Int Angiol 2003;22:438-40.

3 Shih M-CP, Angle JF, Leung DA, et al. CTA and MRA in mesenteric ischemia: part 2, normal findings and complications after surgical and endovascular treatment. Am J Roentgenol 2007; 188:462-71.

Copyright 2013 BMJ Publishing Group. All rights reserved. For permission to reuse any of this content visit http://group.bmj.com/group/rights-licensing/permissions.

BMJ Case Report Fellows may re-use this article for personal use and teaching without any further permission.

Become a Fellow of BMJ Case Reports today and you can:

- Submit as many cases as you like

- Enjoy fast sympathetic peer review and rapid publication of accepted articles

- Access all the published articles

- Re-use any of the published material for personal use and teaching without further permission

For information on Institutional Fellowships contact consortiasales@bmjgroup.com

Visit casereports.bmj.com for more articles like this and to become a Fellow 